\section{Rediscovery of Uniyala multibracteata (Gamble) H. Rob \& Skvarla (Asteraceae) from the southern Western Ghats, India}

\author{
E.S. Santhosh Kumar ${ }^{1}$, P.E. Roy ${ }^{2}$, S.M. Shareef ${ }^{3}$ \\ \& S.S. Usha ${ }^{4}$ \\ 1,2,3 Tropical Botanic Garden and Research Institute, Palode, \\ Karimancode P.O., Thiruvanathapuram District, Kerala 695562, \\ India \\ ${ }^{4}$ Department of Botany, S.N. College, Sivagiri-Varkala, \\ Sreenivasapuram P.O., Kerala 695145, India \\ Email: ${ }^{1}$ santhoshkumares@gmail.com (corresponding author), \\ 22 roytbgri@gmail.com, ${ }^{3}$ shariftbgri@rediffmail.com, \\ ${ }^{4}$ ushakaimanam@gmail.com
}

Robinson \& Skvarla (2009) established the genus Uniyala, a group of seven shrubby species previously placed in Vernonia, distributed in southern India and Sri Lanka, characterized by four or five costate achenes and blunt sweeping hairs on the style branches. Out of the seven species, Uniyala wightiana (Arn.) H. Rob. \& Skvarla is the only species found endemic to Sri Lanka, whereas U. anceps (C.B. Clarke ex Hook.f.) H. Rob. \& Skvarla is distributed both in Sri Lanka and southern India. The rest of the five species, viz. U. bourdillonii (Gamble) H. Rob. \& Skvarla, U. comorinensis (W. Smith) H. Rob. \& Skvarla, U. multibracteata (Gamble) H. Rob. \& Skvarla, U ramaswamii (Hutch) H. Rob. \& Skvarla and U. salvifolia (Wight) H. Rob \& Skvarla are endemic to southern India.

Date of publication (online): 26 May 2012

Date of publication (print): 26 May 2012

ISSN 0974-7907 (online) | 0974-7893 (print)

Editor: N.P. Balakrishnan

Manuscript details:

Ms \# 02968

Received 13 October 2010

Final received 08 March 2012

Finally accepted 27 March 2012

Citation: Kumar, E.S.S., P.E. Roy, S.M. Shareef \& S.S. Usha (2012) Rediscovery of Uniyala multibracteata (Gamble) H. Rob \& Skvarla (Asteraceae) from the southern Western Ghats, India. Journal of Threatened Taxa 4(5): 2587-2589.

Copyright: (c) E.S. Santhosh Kumar, P.E. Roy, S.M. Shareef \& S.S. Usha 2012. Creative Commons Attribution 3.0 Unported License. JoTT allows unrestricted use of this article in any medium for non-profit purposes reproduction and distribution by providing adequate credit to the authors and the source of publication.

Acknowledgement: The authors are grateful to the Director, TBGRI Thiruvananthapuram for constant encouragement and facilities provided.

OPEN ACCESS | FREE DOWNLOAD

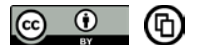

Uniyala multibracteata was originally described as Vernonia multibracteata by J.S. Gamble in 1920. It was known only by a single collection made by Col. R.H. Beddome from Peermedu of the erstwhile Travancore State. Repeated searches to relocate the species in and around its type locality were futile, hence it was treated as an endangered species (Sasidharan 2004). During a floristic exploration to Bonaccord in the Agasthyamala Biosphere Reserve, U. multibracteata was rediscovered (Image 1). The identity was cross matched with the type material housed at the Royal Botanic Gardens, Kew (www.kew.org). It is described and illustrated here (Fig. 1).

Uniyala multibracteata (Gamble) H. Rob. \& Skvarla, Proc. Biol. Soc. Washington 122(2): 153. 2009. Vernonia multibracteata Gamble, Bull. Misc. Inform. Kew 1920: 340. 1920 \& Fl. Pres. Madras 675. 1921; Uniyal, B.P. in Hajra et al. (eds.) Fl. India 13: 374. 1995; Nayar, M.P. \& A.R.K.Sastry (eds.) Red Data Book 1: 90. 1990; Sasidharan, N., Biod. Doc. Kerala. Part 6. Flowering Plants 258. 2004; Nayar T.S.
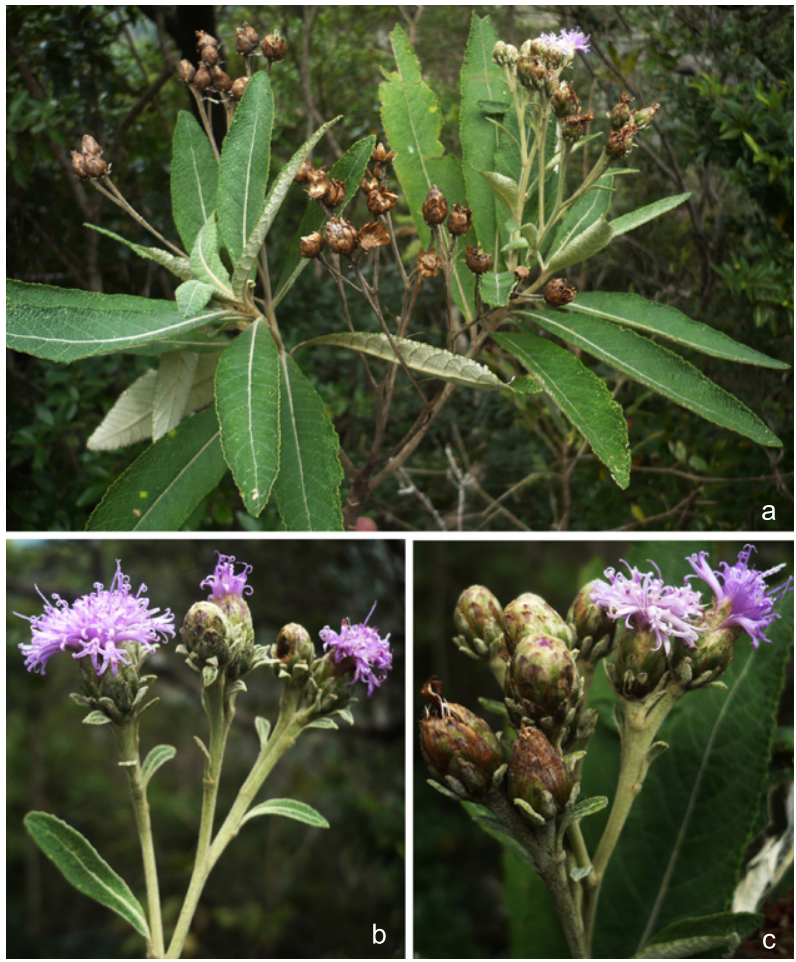

Image 1. Uniyala multibracteata (Gamble) H. Rob \& Skvarla a - Habit; b \& c - Close up of capitula 


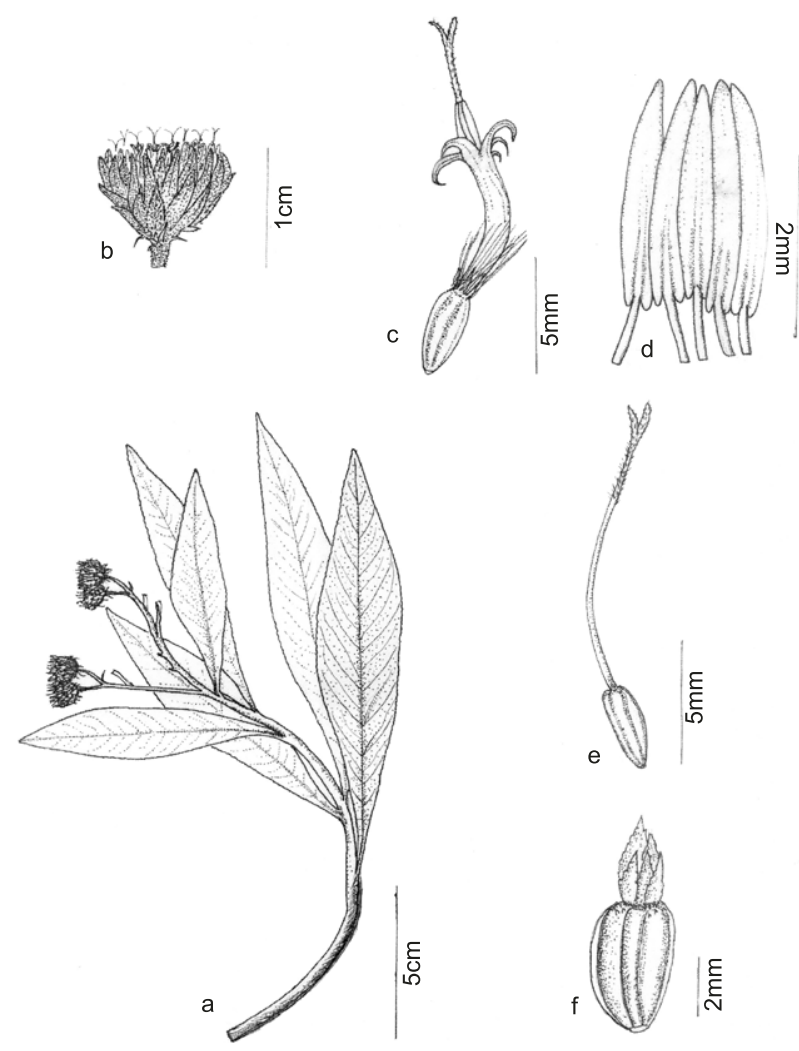

Figure 1. Uniyala multibracteata (Gamble) H. Rob \& Skvarla a - Habit; b - Capitulum; c - Flower; d - Androecium; e- Gynoecium; f - Achene

et al., Fl. P1. Kerala 125. 2006. (Fig.1. a-c; Fig.2.a-f.)

Specimens examined: 28.ii.1991, 1200m, Athirumala, Thiruvananthapuram District, Kerala, India, N. Mohanan 10462 (TBGT); 27.viii.1998, 1400m, ibid, Shaju \& Kiran Raj 34769 (TBGT); 30.xii.2009, Merchiston, E.S. Santhosh Kumar \& P.E. Roy, 69206 (TBGT) (Image 2).

Type: Southern India, Travancore, Peermedu, 1000m, Dec. 1880, Beddome, R.H. s.n. (Digital image, $\mathrm{K})$.

Large shrubs or small trees, to $2 \mathrm{~m}$ high; branchlets thick, white, lanate. Leaves $5-20$ x $0.9-5 \mathrm{~cm}$, lanceolate, acuminate at apex, attenuate-decurrent at base, crenulate at margin, densely white tomentose beneath, dark green and rugose above, lateral nerves $10-18$ pairs, parallel and reticulate; petiole 1-2 $\mathrm{cm}$ long, thick, white-lanate. Capitula in terminal corymbs, 2-4 together covered with white-lanate tomentose hairs; each $10 \times 10 \mathrm{~mm}$. Flowers 30 or more per capitula, purple; peduncle $2-6 \mathrm{~cm}$ long; involucre bracts lanceolate, $1 \mathrm{~cm}$ long; outer long acuminate, araneous, intermediate almost glabrous; inner smaller,

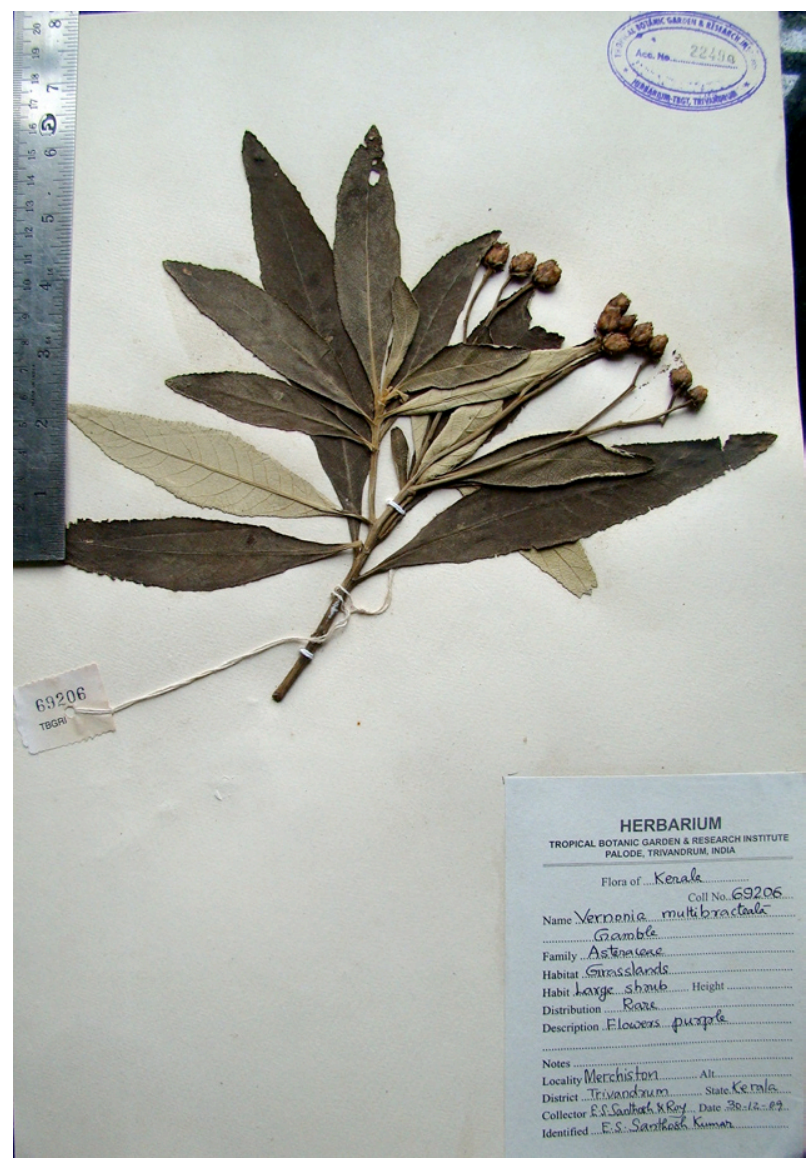

Image 2. Herbarium of Uniyala multibracteata

mucronate. Corolla cylindric, glabrous, to $4 \mathrm{~mm}$ long; lobes short. Stamens 5; anthers 2.5-3 mm long, sagittate at base, exserted. Pollen grains prolate spheroidal, 39.2- 49 × 39.2-47.6 $\mu \mathrm{m}, 3$-zonocolporate, aperture circular, porate, exine lophate, $4.2 \mu \mathrm{m}$ thick, surface lacunate, lacuna circular and elongate, supratectate, muri broad, surface spinate, spine to $3.2 \mu \mathrm{m}$ long, blunt at tip. Ovary oblong, 2.7-3 mm long, narrowed at apex, glandular; style $9.5-10 \mathrm{~mm}$ long; stigma bifid, puberulent. Achene tetragonous, winged, glabrous, pappus hairs biciliate; outer paleaceous, fimbriate; interior bristles setaceous.

Flowering and fruiting: August-March.

Distribution: Endemic to the southern Western Ghats, Kerala.

\section{REFERENCES}

Gamble, J.S. (1920). Bulletin of the Miscellaneous Information of Kew. Royal Botanic Gardens, Kew, 340pp.

Gamble, J.S. (1921). Flora of the Presidency of Madras, 
Adlard \& Sons, London, 675pp.

Nayar, M.P. \& A.R.K. Sastry (1990). Red Data Book of Indian Plants-Vol. 1. Botanical Survey of India, Kolkata, 90pp.

Nayar, T.S., B. Rasiya, N. Mohanan \& G. Raj Kumar (2006). Flowering Plants of Kerala - A Handbook. Tropical Botanic garden and Research Institute, Thiruvananthapuram, $125 \mathrm{pp}$.

Robinson, H \& J.J. Skvarla (2009). A new genus, Uniyala, from peninsular India and Sri Lanka (Vernonieae: Asteraceae). Proceedings of the Biological Society of Washington 122: 150-154.

Sasidharan, N. (2004). Biodiversity Documentation of Kerala-Part 6. Flowering Plants, Kerala Forest Research Institute, Peechi, 258pp.

Uniyal, B.P. (1995). Asteraceae: Vernonieae, pp. 330-394. In: Hajra P.K., R.R. Rao \& D.K. Singh (eds.), Flora of India - Vol. 13. Botanical Survey of India, Kolkata, 412pp. 